\title{
Eksoottinen ja epätavallinen väitöstutkimus
}

\author{
Soila Juden-Tupakka \\ (2000). Daya naisten \\ maailman välittäjänä. \\ Kehitysyhteistyöpro- \\ jektiin osallistuneita \\ yläegyptiläisiä kylä- \\ kätilöitä koskeva tutki- \\ m u s . \\ YLIOPISTOPAINO
}

\section{Soila Juden-Tupakan} väitöskirja osoittaa paitsi laajuudeltaan (270 sivua, 20 sivua lähdeviittauksia) myös sisällöltään tekijän paneutuneen syvällisesti tutkimusaiheeseensa. Väitöskirja sisältää paljon erilaista kasvatustieteeseen, sosiaali- ja kulttuuriantropologiaan, metodologiaan, tieteen historiaan, Egyptin historiaan, egyptiläisten naisten ja dayojen asemaan ja kehitysyhteistyöhön kuuluvaa tietoutta. Lukijana hämmäste- len sitä laajaa lähdemateriaalia, jonka tutkija on työnsä kuluessa läpikäynyt. Materiaalissa olisi aineistoa useaankin tutkimukseen. Lukiessani mietin myös, eikö tekijä olisi voinut valita helpompaa tutkijan tietä ja ottaa opinnäytetyölleen tieteenalalleen tutumpaa aihetta. Tutkimuksen lukeminen oli kuitenkin kiinnostavaa, joten en voi kuin ihailla Juden-Tupakan tietorikasta väitöskirjaa.

\section{Soila Juden-Tupakka}

määrittelee johdantoluvussa väitöskirjansa keskeiseksi tavoitteeksi kuvata ja analysoida, miten daya, yläegyptiläinen rituaalinen kyläkätilö, konstruoi asemansa naisten maailman rituaalien asiantuntijana. Näistä rituaaleista tutkija on rajannut tutkimuksensa koskemaan naisten ympärileikkausta, naisten avioitumista ja immenkalvon puhkaisua.
Tutkimuksen alussa tutkija kuvaa dayojen asemaa egyptiläisessä yhteiskunnassa yleisemmin ja tutkimuksen loppuosassa hän konstruoi dayojen asemaa haastattelujen ja havaintojen perusteella.

\section{Dayojen elämää koskeva} empiirinen aineisto on erittäin monipuolinen. Se perustuu 46 litteroituun haastatteluun, havaintoihin, valokuviin, kenttäpäiväkirjoihin ja tietoihin dayojen koulutuksesta ja koulutuksen historiasta. Aineisto sisältää sekä eksplisiittistä, julkilausuttua, että implisiittistä, sanatonta tietoa. Tutkijan havainnoima sanaton tieto, kuten eleet ja kieltäytyminen vastaamasta kysymyksiin, on ollut tärkeää, koska tutkittavassa kulttuurissa on tabuja, joita ei saa lausua julki. Tutkija on kartoittanut erittäin tarkasti empiirisen ai- 
neiston keräyksen, dokumentoinnin ja käsittelyn eri vaiheet. Hän on myös perusteellisesti ja mielenkiintoisesti eritellyt tutkijan roolia. Tutkijan roolin erittely liittyy nykytutkimuksen mukaiseen keskusteluun objektista ja subjektista ja tutkijan oman tutkijaroolin motiiveista.

Väitöskirjan aihealue on siis eksoottinen ja epätavallinen kasvatustieteen tutkimuskohde. Epätavallinen tutkimustyö ei myöskään sujunut ilman dramatiikkaa. Soila Juden-Tupakka ei joutunut kestämään vain tutkijan painajaisia, kuten hävinneitä tiedostoja, vaikeuksia tutkimuslupien ja rahoituksen saannissa ym. käytännön vaikeuksia, vaan myös alkuperäinen tutkimussuunnitelma kariutui.

\section{Alkuperäinen kehittävän}

työntutkimuksen teoreettinen malli ei toiminut eikä kehitysyhteistyöprojektin dayoja koskeva koulutus toteutunut sen alkuperäisessä muodossa. Tutkija sanoutui tutkimuksessaan irti kehitysyhteistyöprojektista ja esittäytyi kentällä tästä erillisenä yliopiston tutkijana. Egyptiläis-suomalaisiin kehitysyhteistyöprojekteihin jonkin verran tutustuneena olin tehnyt juuri saman valinnan 1980-luvun puolivälissä. Kehitys-yhteistyöprojekteihin ainakin vielä 1980-luvulla sisältyi sekä projektien vetäjien taloudellisia intressejä että eri maiden välistä kilpailua suurimmasta kakusta ilman, että niihin olisi sisällytetty laajakantoi-sempaa kehittämisen ideaa tai kulttuurien tuntemusta.

\section{Sen lisäksi, että} alkuperäinen, teoreettinen lähestymistapa ei toteutunut, myös dayojen haastattelu oli vaikeaa. Teemoittain esitettyjä haastattelurungon kysymyksiä ei ymmärretty, ja koska egyptiläisessä kulttuurissa naiset toimivat ryhmässä, suunnitellut yksiköiden haastattelut muuttuivat ryhmähaastatteluiksi. Myöskään koulutuksen vaikuttavuutta dayoihin ei voitu tutkia, koska kehitysyhteistyöprojektin koulutus kohteina olivat lääkärit ja sairaanhoitajat. Tutkijan uudistettu teoreettinen viitekehys nojaakin antropologisiin käsitteisiin ja teorioihin sekä Herbert Spiegelbergin havaintojen askeleittain syventämistä koskevaan metodologiaan. Kasvatustieteelliset teoriat ja käsitteet on tuotu lisäelementteinä ja ne tuntuvat lukijasta vähän "päälleliimatuilta", eivätkä toimi tutkimuksen ongelmaa selventävinä elementteinä.

\section{Kahden tieteenalan}

väliin asettautuminen ei ole helppo tehtävä. Todennäköisesti tutkija, joka tekee kasvatustieteellistä väitöskirjaa, haluaa liittää siihen oppi-isiensä malleja koulutuksesta. Tutkijan tehtävä on myös ollut vaikea siksi, koska hänen alkuolettamuksensa eivät ole toimineet ja hän on joutunut hakemaan tukea lähinnä sosiaali- ja kulttuuriantropologiasta. Kuten kai yleisesti tiedetään, saa vieraalle tieteenalalle tunkeutuminen tämän tieteenalan edustajat herkistymään ja arvioimaan tutkimusta ehkä liiankin kriittisesti omasta näkökulmastaan.

\section{En tunne kasvatus-}

tieteellistä tutkimusta kovin hyvin, mutta ihmettelen, eikö kasvatustieteessä tai kas- vatusantropologiassa tietoa voi soveltaa ilman, että siihen sisältyisi ajatusta kouluttajasta tai kasvattajasta ja heidän interventionsa kohteista. Mielestäni oppiminen ja kehitys kattaa ihmisen koko elämänkulun ja siihen sisältyvät kaikki vuorovaikutussuhteet, eivätkä vain koulutus/kasvatustapahtumaan liittyvät ilmiöt.

\section{Soila Juden-Tupakka}

(Aikuiskasvatus 3/2000, s. 234-39) käsitteleekin kasvatustieteiden/kasvatusantropologian tehtäviä Aikuiskoulutus-lehdessä puoli vuotta väitöskirjansa ilmestymisen jälkeen. Hän esittelee artikkelissaan kasvatusantropologian uusimpina suuntauksina ihmisten välisten vuorovaikutusten malleja, joissa otetaan laajasti huomioon ihmisen sosiaalistuminen kulttuuriin. Ideat olisivat sopineet jo hänen omaan väitöskirjaansa. Tämäntyyppistä lähestymistapaa väitöskirjassa kylläkin on, vaikka sitä ei teoretisoida, eikä esitellä uuden kasvatusantropologian lähestymistapana. Esimerkkinä tästä ovat $\mathrm{mm}$. dayojen ammatin periytyminen ja dayojen ja hoitohenkilökunnan keskinäistä vuorovaikutusta koskevat kuvaukset.

\section{Liminaalisuus, jota} tutkija käyttää keskeisenä teoreettisena käsitteenä, on lähtöisin antropologisesta tutkimustraditiosta. Tutkija analysoi antropologiseen kirjallisuuteen perustuvaa liminaalisuuden, liminaaliaiheiden sekä niihin liittyvien siirtymäriittien ja rituaalien käsitteitä. Liminaalisuudelle ja liminaalivaiheelle on ominaista, että ne käsitetään väliaikaisiksi tiloiksi ja että ne eroavat 
täten syrjäytymisestä, joka käsitetään lopullisemmaksi yhteisöstä irtaantumiseksi. Liminaalivaiheisiin liittyvien siirtymäriittien ja rituaalien luonne vaihtelee eri yhteisöissä. Yhteistä näille kuvauksille on kuitenkin riittien ja rituaalien liittyminen henkilöiden kohtaamiin vaaratilanteisiin tai kriiseihin, joita pyritään estämään erilaisilla toiminnoilla. Tarkastelun lopputuloksena tutkija esittää siirtymäriittejä ja rituaaleja havainnollistavan kaavion dayan tehtävistä eri yläegyptiläisen naisen eri liminaalivaiheissa.

\section{Empiirisen aineiston}

kuvaus perustuu tarkkaan ja huolellisesti tehtyyn dokumentointiin. Joiltakin osin senkaltaista empiiristä kuvausta, joka ei suoranaisesti liity yläegyptiläisen dayan toimintaan, olisi voitu supistaa. Tutkimuksen empiirisessä osassa käytetty Herbert Spielbergin ajatuksiin pohjautuva aineiston kuvaus fenomenologisten askelten mukaan toimii tutkimuksessa hyvin ja auttaa jäsentämään aineistoa. Sen sijaan grounded-teorian sovellus tuottaa luettelomaista tietoa. Grounded-teorian pohjalta jatkokäsittelyyn valittu ydinkategoria sisälsi sekä kunnian että häpeän ulottuvuudet. Kun kunnia ja häpeä ovat yleisesti antropologisessa kirjallisuudessa keskeisiä kulttuurisia merkityksiä selittäviä tekijöitä, olisi grounded-teorian asemasta myös voitu käyttää tekstianalyysia, jolloin saaduista empiirisistä tiedoista olisi voitu laajemmin analysoida syy- ja seuraussuhteita sekä verrata saatuja tuloksia tätä aihetta koskevaan kirjallisuuteen.

\section{Kokonaisuudessaan}

tutkimus on erittäin mielenkiintoista luettavaa. Luettavuuden nautintoa häiritsevät jo edellä mainitsemani kasvatustieteiden teorioiden huono sulautuminen tekstiin ja myös joissakin kohdin liian monet lainaukset muilta tutkijoilta. Tutkija ikään kuin pakenee jonkun auktoriteetin taakse eikä uskalla ilmaista sanottavaansa omin sanoin. Väitöstilaisuudessa Soila JudenTupakka vastasi kysymyksiin erittäin selkeästi ja selvensi vastaväittäjille epäselviksi jääneitä kohtia. Ihmettelin sitä, miksi väittelijä, joka pystyy niin loistavaan argumentointiin puheessaan, ei aina pysty siihen kirjallisessa muodossa.
Vieraalle kulttuurille ominaisen ilmiön analysointi on tulkinnallisesti vaikeaa. Lukemani ja egyptiläistä kyläkulttuuria koskevien tietojeni perusteella on todettava, että tutkija on pystynyt välittämään oleellista tietoa yläegyptiläisen naisen liminaalivaiheista ja dayan merkityksestä näihin liittyvien riittien ja rituaalien valvojana ja toteuttajana. Dayajoista tehty tutkimus on kansainvälisesti harvinainen tutkimuskohde, joka paitsi avaa oven yläegyptiläisten maaseudun naisten maailmaan, sisältää tärkeitä tietoja, joita voidaan käyttää erilaisten kehitysyhteistyöprojektien toteutuksessa. Toivoisinkin, että väitöskirjaa eivät lukisi vain aiheesta kiinnostuneet tutkijat, vaan myös kehitysyhteistyöprojektien suunnittelijat ja vetäjät.

\section{Viite}

Juden-Tupakka, Soila: Kasvatusantropologisen tutkimuksen havaintoja kehitysyhteistyön koulutuksessa. Aikuiskasvatus 3/2000, 234-239)

Espoossa 7.12.2000

Päivi Elovainio 